\title{
Trote e cidadania
}

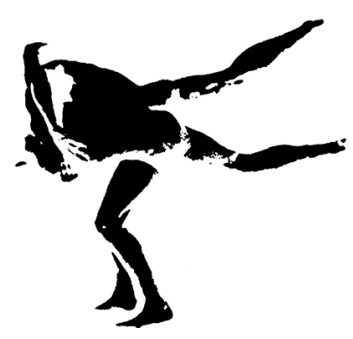

Marcelo Coltro ${ }^{1}$

Será o trote tradicional salutar para o convívio universitário ou um ritual despolitizado e brutalizador? Entender a problemática que envolve o trote nas universidades é um primeiro ponto de reflexão para a transformação desta prática, sem que para isso seja necessário esperar novas tragédias. Segundo seu conceito, o "trote" é um ato de zombaria a que os veteranos das escolas sujeitam os calouros, ou seja, uma ridicularização e desdém a que o novo universitário será exposto. Entendendo desta forma, não há como ser a favor de uma prática que transforma o sonho de conquistar a cidadania $e$ a busca do conhecimento num ato de subjugação, ferindo todos os preceitos universitários.

O trote tem suas raízes na Academia como prática milenar. Na Idade Média, estudantes de vários países, unidos pelo latim como língua universal, procuravam a universidade como uma chance de ascensão social. Nobres, pequena nobreza, burguesia e camponeses compunham a universidade. Consolidadas por seu caráter urbano, as instituições ofereciam tratamento diferenciado para cada um. Numa época de desprezo e discriminação para com o mundo rural, aos camponeses, julgados rústicos, restava o trote. Jacques Le Goff (p.69-70) expressa muito bem essa condição de desprezo: "...zomba-se de seu odor de besta-fera, de seu olhar perdido, de suas longas orelhas, de seus dentes parecendo presas. Extraem-lhe supostos chifres e excrescências. Banham-lhe e limam-lhe os dentes. Em uma paródia da confissão, ele enfim reconhece vários vícios".

\footnotetext{
${ }^{1}$ Quinto-anista de Medicina na Universidade Federal de Pelotas; coordenador geral da Denem - Direção Executiva Nacional dos Estudantes de Medicina.
} 
Segundo Paulo Denisar Vasconcelos, "o trote caracteriza-se como um rito de iniciação; é um cerimonial milenar de agressão e violência contra o calouro: confirma a idéia do trote como um rito de passagem às avessas, como prática oposta aos valores humanistas e civis da universidade”. Que isso aconteça em um país que faz sacrifícios desmedidos para possuir "universidades" e que precisa delas para acelerar seu desenvolvimento é um paradoxo. O que importa assinalar é que não sairemos da atual situação sem mudanças radicais de mentalidade - não só dos "universitários", mas dos que podem absorver os produtos do seu trabalho ou contribuir para o alargamento das esferas de influência dos serviços de ensino e de pesquisa das universidades.

A recepção politizada aos calouros é salutar para o convívio universitário $e$ deve ser desenvolvida e trabalhada dentro das instituições. Permite que os calouros, e não os "bixos" como na Idade Média, compreendam a universidade e passem a conviver mais de perto com conceitos de autonomia. A recepção deve ser encarada como um rito de iniciação necessário, capaz de produzir massa crítica desde o início da vida acadêmica e de levar a escola a ultrapassar seus muros, transformando a educação profissional, formal e não formal. $O$ trote pode ser parte de um projeto educativo global, integrado e articulado na luta por uma educação de qualidade para todos, que acabe gerando indivíduos capazes de estabelecer seus próprios limites de intervenção na sociedade. Esta prática de recepção já existe em várias universidades do país, mas é preciso difundi-la. A versão despolitizada e bruta do trote é uma herança deixada pelo AI-5, de 1968, que acirrou o controle sobre as universidades e impediu a manifestação político-cultural das calouradas estudantis, que se constituíam, na época, em espaços de contestação e de crítica social. Não podemos mais viver das heranças e nem vivenciar a democracia da idade média. Afinal, os tempos são outros...

\section{Referências bibliográficas:}

VASCONCELOS, P. D. A violência no escárnio do trote tradicional - um estudo filosófico em antropologia cultural. Santa Maria-RS: Universidade Federal de Santa Maria, 1993. p.14-5.

LE GOFF, J. Os intelectuais na Idade Média. São Paulo: Braziliense, 1989. 